\title{
Factors Influencing Market Participation by Smallholder Farmers in Masvingo and Manicaland Provinces, Zimbabwe
}

\author{
Lighton Dube \\ Graduate School of Business, Zimbabwe Open University, Harare, Zimbabwe
}

Email address:

dubelig@gmail.com

\section{To cite this article:}

Lighton Dube. Factors Influencing Market Participation by Smallholder Farmers in Masvingo and Manicaland Provinces, Zimbabwe. International Journal of Agricultural Economics. Vol. 5, No. 6, 2020, pp. 313-320. doi: 10.11648/j.ijae.20200506.20

Received: November 7, 2018; Accepted: January 17, 2019; Published: December 8, 2020

\begin{abstract}
Markets play a critical role in economic development and strengthening market participation by smallholder farmers in both input and output markets is critical for the development of smallholder agriculture in Zimbabwe. This study analyzes the determinants of output markets participation in Masvingo and Manicaland provinces using data from a random sample 479 smallholder farmers. Market participation is very low with only $19 \%$ of the sample farmers participating in output markets. Results of the binary logistic regression show that the variables that have a positive and significant effect on outputs market participation are age of the head of household, the size of the household, the level of education of the head of household, the household agricultural income, the degree of farm specialization, access to irrigation, access to draft power, on demand extension service, quality of extension support, distance of the farm from the nearest rural business centre and tenure. Gender of the head of household, the level of education of household members, farming experience, the block training approach, the level of dependency, the farmer to farmer extension approach and household members with off-farm employment significantly and negatively influence market participation. In order to enhance smallholder farmers' participation in output markets, the study recommends that policy intervention efforts must primarily focus on expanding access to irrigation and draft power as well as improving the quality of extension support services for the farmers.
\end{abstract}

Keywords: Smallholder Farmers, Market Participation, Binary Logistic Regression, Zimbabwe

\section{Introduction}

Commercialization of smallholder agriculture through increased participation of smallholder farmers in formal markets is a critical requirement for the economic growth and development for most developing countries relying on the agricultural [1-4]. According to the World Bank [5], improving productivity, profitability and sustainability of smallholder farming is the main pathway to reduce poverty in the developing countries. Markets play an important role in rural development, employment creation, income generation, food security, technology diffusion, enhancing resource use efficiency, and developing rural-market linkages. Markets availability and enhancing the ability of smallholder and resource- poor rural farmers to access market opportunities and diversify their links with markets is therefore a prerequisite for enhancing agriculture-based economic growth and increasing rural incomes [4, 6-7]. The recognition of the potential of markets to unlock economic growth and agricultural development gave rise to market-led rural development paradigm during the 1980s [8].

In most developing countries, smallholder farmer participation in formal output markets is limited as most production is mostly for subsistence needs with little surplus production for marketing. Even in situations where smallholder farmers are producing a surplus, their participation in formal output markets is hampered by a number of challenges [7]. These challenges include unavailability of markets, poor marketing infrastructure, insufficient surplus production to cover marketing related costs, limited business and negotiating experience and collective bargaining skills, poor packaging of farm produce, and lack of access to marketing information and market intelligence among others.

In Zimbabwe, there has been a major shift for market-led agricultural development in recent years following the marked reduction of government spending in smallholder agriculture. In the past, the government used to play a pivotal 
role in assisting farmers with the marketing of their agricultural produce through a number of commodity based statutory marketing boards. However, following the liberalization of the agricultural markets in the 1980s and the 1990s in an effort to create open market-led exchange aimed at boosting economic growth, most smallholder farmers are experiencing difficulties in participating in formal agricultural output markets. Understanding the factors that drive smallholder famers to participate in agricultural output markets is critical for developing measures to promote and enhance their participation and improving their livelihoods.

The major objective of this study is to assess the factors affecting market participation in output markets by smallholder farmers in Masvingo and Manicaland provinces of Zimbabwe. Specifically, the study provides responses to the following questions: What is the level of market participation in output markets by smallholder farmers in Masvingo and Manicaland provinces of Zimbabwe? What factors determine market participation in output markets by smallholder farmers Masvingo and Manicaland provinces of Zimbabwe?

\section{Methodology}

\subsection{Study Area, Population and Sample}

This study is based on survey data collected in March 2015 from the 6 districts that GIZ is implementing the Agricultural Innovation Support Project (GIZ AISP). The districts are Nyanga, Mutasa and Mutare districts in Manicaland province; and Chiredzi, Zaka and Bikita in Masvingo province. The sample was drawn from a total population of 30,000 farming households. Using the Raosoft sample size calculator (www.raosoft.com/samplesize.html), the minimum sample size target for the household survey was set at 350 farming households. This target sample size was based on achieving a $5 \%$ margin of error and a $95 \%$ confidence level.

479 sample farming households were selected using a multi-stage random sampling approach. The first stage involved randomly selecting two wards in each of the six districts. The second stage involved randomly selecting two farming household groups from each of the two randomly selected wards in each of the six districts. One group selected was for farming households who had benefitted from GIZ AISP support through improved extension services and the other group was for non-beneficiary farming households. Lastly, all available farming households in each selected group were interviewed for the study.

\subsection{Data Analysis}

The level of commercialization of a farmer is used as a proxy for market participation in this study [1]. Households who sell less than $60 \%$ of their produce are classified as non-market participant and those who sell at least $60 \%$ of their produce are classified as market participant. Thus market participation is measured as a binary variable where 1 represents a household participating in output markets and 0 otherwise $[9,10]$.

A binary logistic regression model is used for assessing the factors that affect smallholder market participation in output markets by the sampled farming households. The variables used in the model, their explanation and the a priori expectations are provided in Table 1.

Table 1. Definition of Variables.

\begin{tabular}{|c|c|c|c|}
\hline Variable & Description & Variable Measurement & Hypothesis \\
\hline \multicolumn{4}{|c|}{ DEPENDENT VARIABLE } \\
\hline FMARKET & Farmer participates in output markets & Dummy: $1=$ yes, $0=$ otherwise & \\
\hline \multicolumn{4}{|c|}{ INDEPENDENT VARIABLES } \\
\hline HHGENDER & Gender of household head & Dummy: $1=$ male, $0=$ otherwise & $-/+$ \\
\hline HHAGE & Age of household head & Years & - \\
\hline HHSEDUC & Head of households has at least secondary education & Dummy: $1=$ yes, $0=$ otherwise & + \\
\hline HHSIZE & Household size & Number of people in a household & + \\
\hline MEMOFFY & Household members employed off farm & Number of members & - \\
\hline HMSEDUC & Household members with secondary education & Number of members & + \\
\hline DRATIO & Dependency ratio & $\begin{array}{l}\text { Ratio of those younger than } 15 \text { years plus those older than } \\
64 \text { years to the working age population (those with ages } \\
\text { between } 15-64 \text { years) }\end{array}$ & - \\
\hline YRSFARM & Farming experience & Number of years farming & \\
\hline FARMGV & $\begin{array}{l}\text { Farm gross value based on crop and livestock production } \\
\text { (measure of farm productivity) }\end{array}$ & United States dollar value of total annual farm produce & + \\
\hline FSPEC & Degree of farm specialization & Measured using the Herfindahl Index for area cultivated & + \\
\hline IRRIG & Household access to irrigation & Dummy: $1=y e s, 0=$ otherwise & + \\
\hline DRAFT & Household access to draft power & Dummy: $1=y e s, 0=$ otherwise & + \\
\hline TENURE & Household has communal tenure & Dummy: $1=y e s, 0=$ otherwise & - \\
\hline $\mathrm{EXT}_{\mathrm{DEM}}$ & $\begin{array}{l}\text { Household has access to extension on demand over the past } \\
12 \text { months }\end{array}$ & Dummy: $1=y e s, 0=$ otherwise & + \\
\hline EXTB $_{\text {TRAIN }}$ & Household participated in block extension training & Dummy: $1=y e s, 0=$ otherwise & + \\
\hline $\mathrm{EXT}_{\mathrm{QUAL}}$ & Household has access to quality extension & Dummy: $1=y e s, 0=$ otherwise & + \\
\hline $\mathrm{EXT}_{\mathrm{F} 2 \mathrm{~F}}$ & $\begin{array}{l}\text { Household received farmer-to-farmer extension over the } \\
\text { past } 12 \text { months }\end{array}$ & Dummy: $1=y e s, 0=$ otherwise & + \\
\hline $\mathrm{EXT}_{\text {VISITS }}$ & Extent of extension visits over the past 12 months & Number of extension visits & + \\
\hline $\operatorname{ASSET}_{\text {INDEXT }}$ & Measure of household wealth or wellbeing & Measured using a Household Asset Index (1 - 100\%) & + \\
\hline $\mathrm{DIST}_{\mathrm{GP}}$ & Distance from farm to nearest growth point & Distance in kilometres & - \\
\hline
\end{tabular}




\section{Results and Discussion}

\subsection{Socioeconomic Characteristics of the Sample Households}

The socioeconomic characteristics of the sample households are presented in Table 2 below. $61 \%$ of the sample households are male headed and the average age of the head of households is 50 years. $42 \%$ of the head of households have at least secondary education and the average household size is 5.87 members.

Table 2. Summary Statistics of the Sample Households.

\begin{tabular}{|c|c|c|}
\hline Variable & Mean & Standard Deviation \\
\hline FMARKET & 0.19 & 0.396 \\
\hline HHGENDER & 0.61 & 0.489 \\
\hline HHAGE & 49.80 & 15.271 \\
\hline HHSEDUC & 0.42 & 0.494 \\
\hline HHSIZE & 5.87 & 2.390 \\
\hline MEMOFFY & 0.33 & 0.472 \\
\hline HMSEDUC & 1.69 & 1.521 \\
\hline DRATIO & 3.41 & 2.536 \\
\hline YRSFARM & 20.85 & 16.365 \\
\hline FARMGV & 944.47 & 2207.499 \\
\hline FSPEC & 0.54 & 0.221 \\
\hline IRRIG & 0.11 & 0.319 \\
\hline DRAFT & 0.70 & 0.459 \\
\hline TENURE & 0.83 & 0.379 \\
\hline $\mathrm{EXT}_{\mathrm{DEM}}$ & 0.13 & 0.331 \\
\hline EXTB $_{\text {TRAIN }}$ & 0.23 & 0.418 \\
\hline $\mathrm{EXT}_{\mathrm{QUAL}}$ & 0.67 & 0.471 \\
\hline $\mathrm{EXT}_{\mathrm{F} 2 \mathrm{~F}}$ & 0.43 & 0.495 \\
\hline $\mathrm{EXT}_{\text {VISITS }}$ & 26.50 & 26.150 \\
\hline $\mathrm{ASSET}_{\text {INDEXT }}$ & 10.93 & 5.160 \\
\hline $\mathrm{DIST}_{\mathrm{GP}}$ & 13.03 & 11.765 \\
\hline
\end{tabular}

On average 0.33 members were employed off-farm and the average household members with at least secondary education is 1.69. The dependency ratio for the sample households is 3.41 . The average farming experience for the heads of households is 21 years.

The average agricultural income as measured by the gross value of farm output for the 2014/2015 agricultural season for the sample households is $\$ 944.47$. The farmers are relatively specialized with an average herfindahl index of 0.54. A majority $(83 \%)$ of the sample households have communal tenure while only $11 \%$ of the households have access to irrigation facilities. $70 \%$ of the sample households have access to draft power for their farming operations.

The sample households are receiving on average 26.5 extension visits per month and the proportion of farmers receiving extension support on demand is very low at $13 \%$. $23 \%$ of the farmers have received training through the block extension approach. In this study, the block training approach refers to a training in which the farmers are trained all the agronomic practices in one continuous session. $67 \%$ of the farmers perceived the extension support they are receiving to be of good to high quality while $43 \%$ of the farmers indicated that they are receiving extension support from other fellow farmers.

The average distance of the farms from the nearest growth point (rural business centre) is 13 kilometres. The average wealth of the sample households as measured by the total assert index is 10.93 .

\subsection{Extent of Market Participation in Output Markets by Sample Households}

Market participation is low as only $19 \%$ of the sample households participate in output markets. This result shows that a majority of the sample households are producing for subsistence purposes. A comparison by gender shows that market participation is almost similar for both female headed households and male headed households (Figure 1).

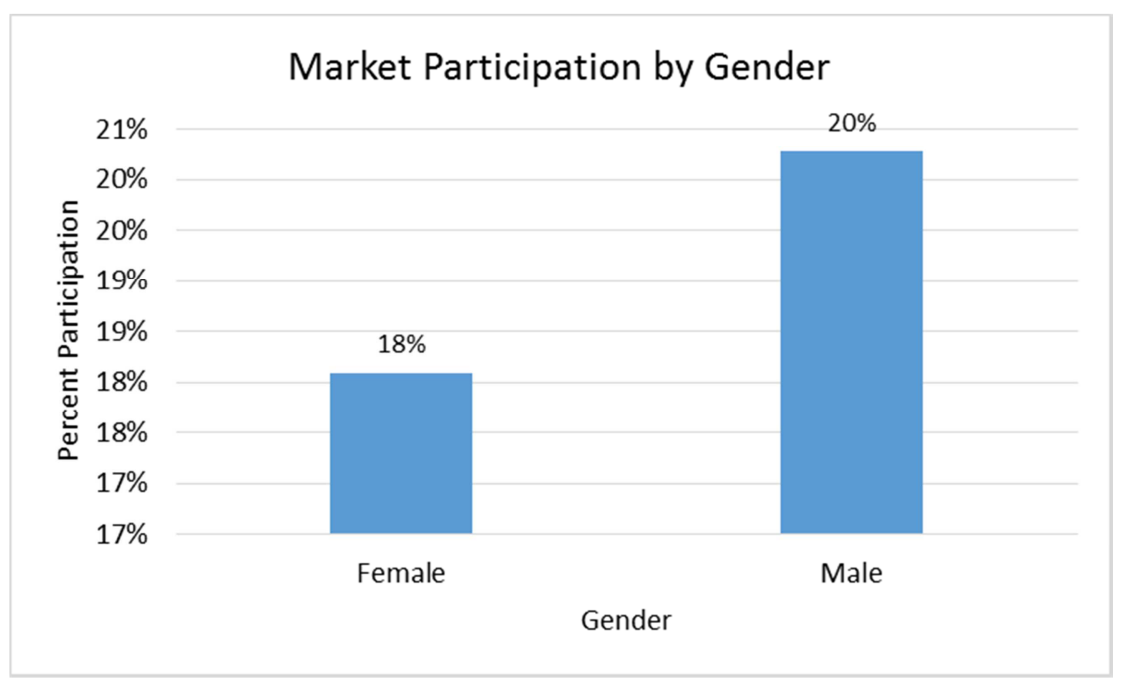

Figure 1. Market participation by gender.

An analysis of market participation by district shows that Chiredzi and Mutasa districts have the highest proportion of farmers participating in the output markets at 35\% and 30\% respectively while Nyanga has the lowest proportion at $10 \%$ 
(Figure 2).

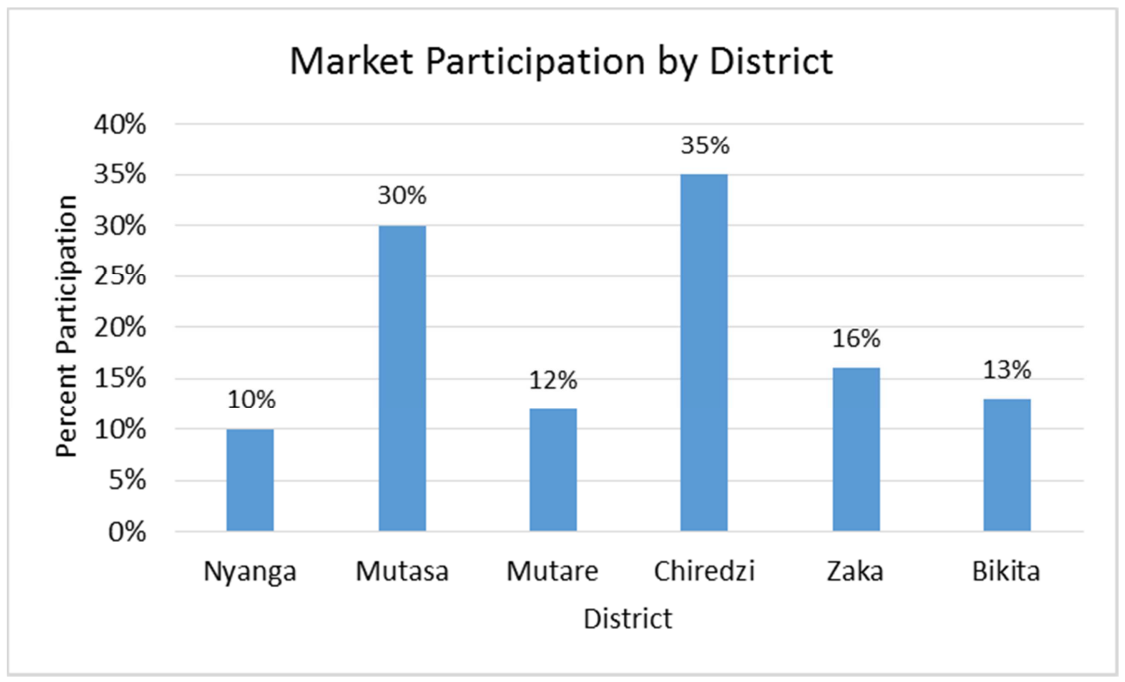

Figure 2. Market participation by district.

\subsection{Determinants of Market Participation}

The estimates of the binary logistic regression are presented in Table 3 below. All the variables significantly influence market participation except for the number of extension visits $\left(\mathrm{EXT}_{\mathrm{VISITS}}\right)$ received by a farmer.

Table 3. Logistic regression estimates of the determinants of market participation.

\begin{tabular}{|c|c|c|c|c|c|}
\hline Independent Variables & B & S. E. & Wald & Sig. & $\operatorname{Exp}(B)$ \\
\hline HHGENDER & -5.528 & 2.074 & 7.103 & 0.008 & 0.004 \\
\hline HHAGE & 0.070 & 0.035 & 4.031 & 0.045 & 1.072 \\
\hline HHSEDUC & 3.307 & 1.424 & 5.395 & 0.020 & 27.292 \\
\hline HHSIZE & 1.903 & 0.730 & 6.801 & 0.009 & 6.703 \\
\hline MEMOFFY & -2.599 & 1.184 & 4.823 & 0.028 & 0.074 \\
\hline HMSEDUC & -2.084 & 0.694 & 9.011 & 0.003 & 0.124 \\
\hline DRATIO & -2.286 & 0.889 & 6.610 & 0.010 & 0.102 \\
\hline FARMGV & 0.006 & 0.002 & 10.878 & 0.001 & 1.006 \\
\hline FSPEC & 6.896 & 3.105 & 4.931 & 0.026 & 987.830 \\
\hline IRRIG & 11.289 & 3.535 & 10.196 & 0.001 & 79923.841 \\
\hline DRAFT & 6.963 & 2.168 & 10.316 & 0.001 & 1056.594 \\
\hline TENURE & 3.310 & 2.030 & 2.659 & 0.103 & 27.398 \\
\hline $\mathrm{EXT}_{\mathrm{DEM}}$ & 4.843 & 1.877 & 6.660 & 0.010 & 126.855 \\
\hline EXTB $_{\text {TRAIN }}$ & -4.628 & 1.843 & 6.306 & 0.012 & 0.010 \\
\hline $\mathrm{EXT}_{\mathrm{QUAL}}$ & 4.775 & 1.725 & 7.662 & 0.006 & 118.497 \\
\hline $\mathrm{EXT}_{\text {VISITS }}$ & 0.021 & 0.017 & 1.538 & 0.215 & 1.021 \\
\hline ASSET $_{\text {INDEXT }}$ & -0.315 & 0.151 & 4.346 & 0.037 & 0.730 \\
\hline $\mathrm{DIST}_{\mathrm{GP}}$ & 0.262 & 0.085 & 9.405 & 0.002 & 1.299 \\
\hline CONSTANT & -21.931 & 6.713 & 10.674 & 0.001 & 0.000 \\
\hline
\end{tabular}

-2 Log likelihood $=51.129$.

Cox \& Snell R Square $=0.503$.

Nagelkerke R Square $=0.787$.

Percent correct prediction $=94.4$.

Gender of the head of household (HHGENDER) negatively and significantly affect farmer market participation. The odds show that the probability of a male headed household participating in the marketing of farm output is 0.996 lower compared to that of a female headed household and this result is significant at $1 \%$ level of significance. Although this result is not expected, it is consistent with the findings of Onoja et al. [11] and Abu [12].
Female headed households are likely to participate in output markets as they have to shoulder the economic and social responsibilities as heads. The age of the head of household (HHAGE) positively and significantly influence market participation and the result is significant at 5\% level of significance. A one-year increase in the age of the head of household increases the probability of the farmer's market participation by a factor of 1.072 . This result is supported by 
the findings of Matungul et al. [13], Randela et al. [14] and Adenegan et al. [15] who argue that old heads of households are more experienced in the markets and this helps them to overcome transaction costs.

There is a positive and significant relationship between market participation and the educational status of the head of household (HHSEDUC) and this result is significant at 5\% level of significance. Head of households who have attained at least secondary level are 27.292 times more likely to participate in agricultural output markets when compared to their counterparts with no secondary education and this result is consistent with the finding of Adeoti et al. [7], Geoffrey et al. [16], Mengstu et al. [17] and Ahmed et al. [18]. Thus farmers with more formal education are more marketoriented as they have the knowledge and skills to be to be able to engage in marketing effectively. Household size (HHSIZE) was also found to positively and significantly influence market participation and the result is significant at $1 \%$ level of significance. An additional family member increases the probability of the farmer's market participation by a factor of 6.703 . This result is consistent with the finding of Mengstu et al. [17], Onoja et al. [11], Nuri et al. [19] and Kassa et al. [20] and one explanation could be that bigger families have more family labour to produce surpluses for the market.

There is a negative and significant relationship between market participation and the number of household members employed off-farm (MEMOFFY) and this result is significant at $5 \%$ level of significance. An additional family member employed off-farm reduces the probability of the household's market participation by a factor of 0.074 . This result is in line with Ahmed et al. [18] and it maybe because off-farm employment offers better incomes that agriculture. Household members employed off-farm also don't have enough time to engage in family farm operations. The results also show a negative and significant relationship between market participation and the number of household members with at least secondary education (HMSEDUC). An additional family member with at least secondary education reduces the probability of the household's market participation by a factor of 0.124 and this result is significant at $1 \%$ level of significance. This finding maybe explained by the fact that better educated household members tend to seek off-farm employment which is more paying than farming. Off-farm employment also reduces the amount of family labour available for farming activities.

A negative and significant relationship exist between market participation and the dependency ratio (DRATIO) and the result is significant 5\% level of significance. Each additional dependent in the household decreases the probability of household market participation by a factor of 0.102 . Households with higher dependents consume more of their agricultural output reducing marketable surplus and the dependents do not also contribute to farming labour $[14,17$, 21].

Farming experience (YRSFARM) negatively and significantly influences market participation. An additional year of farming experience reduces the probability of a household market participation by a factor of 0.907 and this result is significant at $5 \%$ level of significance. This result is not expected although it is supported by Oparinde and Daramola [4] and Siziba et al. [22].

Agricultural income (FARMGV) has a positive and significant relationship with market participation and the result is significant at $1 \%$ level of significance. A unit increase in agricultural income increases the probability of household market participation by a factor of 1.006 . Households earning high agricultural incomes can afford to cultivate large farm sizes and purchase productivity enhancing inputs leading to high output and then large marketable surpluses $[10,12,23]$. Farm specialisation (FSPEC) positively influences household market participation and the result is significant at 5\% level of significance. A unit increase in the level of specialisation increases the probability of market participation by a factor of 987.830. This implies that highly specialized households are more likely to produce high marketable surpluses than relatively diversified households as they concentrate their labour and management skills towards a few enterprises.

Access to irrigation (IRRIG) positively and significantly influences market participation and the result is significant $1 \%$ level of significance. The odds indicate that the probability of a household with access to irrigation participating in output markets is 79922.841 higher than that of a household with no irrigation. This result is supported by Temesgen [23], Hagos et al. [24], Seyoum et al. [25] and Tufa et al. [26]. Water is a very critical agricultural input and access to irrigation facilities allows farmers to increase productivity, produce all year round, induce shifts in farmers cropping mix and also to produce high value horticultural crops for the market. There is also a positive and significant relationship between draft power (DRAFT) and market participation. The probability of a household market participation increases by a factor of 1056.594 for households with draft power when compared to households without and this result is significant at $1 \%$ level of significant. Draft power is a critical input in in both production and transportation of marketable surplus to markets [14, 18, 27-29].

Tenure (TENURE) positively influences market participation and the result is significant at $10 \%$ level of significance. The probability of market participation increases by a factor of 27.398 for farmers with communal tenure when compared to farmers with other forms of tenure. This result is not expected as communal tenure is perceived to be the most unsecure tenure and development practitioners often argue that it constrains farmers' access to credit, farm investments, technology adoption and sustainable agricultural development and productivity [30]. A possible explanation for this result is that the government and development actors have been organising communal farmers into marketing groups and as a result this has improved the capacity of communal farmers to engage markets.

The probability of market participation increases by a 
factor of 126.855 for farmers who receive on-demand extension support $\left(\mathrm{EXT}_{\mathrm{DEM}}\right)$ when compared to farmers who receive the routine general extension support and this result is significant at 5\% level of significance. Extension is a very critical input in improving agricultural productivity and farmers who receive extension on demand are more likely to receive extension support more relevant to their farming needs when compared to farmers who rely on routine general extension support. This result is supported by Mengstu et al. [17], Kassa et al. [20] and Zamasiya et al. [31]. Farmers trained using the block training approach $\left(\right.$ EXTB $\left._{\text {TRAIN }}\right)$ are more likely not to participate in output markets by a factor of 0.010 when compared to farmers trained using other farmer training approaches and this result is significant at 5\% level of significance. A possible explanation for this result could be that it is difficult for farmers to master all production and marketing aspects if the training is offered in one session instead of offering it stage by stage throughout the production cycle as it allows farmers to immediately apply what they would have been trained on.

The probability of market participation increases by a factor of 118.467 for farmers who perceive to be receiving good to high quality extension support $\left(\mathrm{EXT}_{\mathrm{QUAL}}\right)$ when compared to farmers who receive extension support that they perceive not to be of good quality and this result is significant at $1 \%$ level of significance. Farmers are more likely to follow extension advice if it addresses their farming needs. The results also show that the odds of a household participating in output markets is 0.0944 lower for a household receiving extension support from other farmers $\left(\mathrm{EXT}_{\mathrm{F} 2 \mathrm{~F}}\right)$ when compared to a farmers receiving extension support from other sources and the result is significant at $5 \%$ level of significance.

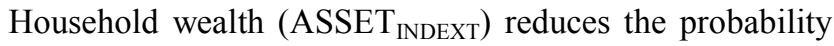
of market participation by a factor of 0.730 and the result is significant at $5 \%$ level of significance. This result shows that the probability of a farmer participating in output markets reduces as the wealth of the farmer increases. This maybe because the wealthy households have enough nonagricultural assets to sustain their livelihoods without necessarily depending on income from sale of agricultural marketable surplus.

Distance from the nearest growth point (rural business centre) (DIST $\mathrm{GP}_{\mathrm{GP}}$ positively and significantly influences market participation. An additional kilometre away from the growth point increases the probability of a household's market participation by a factor of 1.299 . This result supports the finding of Randela et al. [14]. This implies that farmers facing relatively longer distance to the nearest rural business centre are likely to be commercial farmers. Rural business centres offer opportunities for off-farm employment and incomes for those farmers who stay closer to these centres. As you increase distance from these centres, it becomes expensive for farmers to either rent accommodation or commute from their farms to work and as a result, they tend to concentrate on agriculture for livelihood.

\section{Conclusion}

This paper analysed the factors that influence participation in output markets by smallholder farmers in Masvingo and Manicaland provinces of Zimbabwe. The study found that the level of market participation was very low with an average of $19 \%$ of the sample households participating in output markets.

The variables that significantly and positively influence market participation by smallholder farmers are the age of the head of household, the size of the household, the level of education of the head of household, the household agricultural income, the degree of farm specialization, access to irrigation, access to draft power, on demand extension service, quality of extension support, distance of the farm from the nearest rural business centre and tenure. On the other hand, the variables that negatively and significantly influence market participation are gender of the head of household, the level of education of household members, farming experience, the block training approach, the level of dependency, the farmer to farmer extension approach and household members with off-farm employment.

In order to enhance smallholder farmers' participation in output markets, policy intervention efforts must primarily focus on expanding access to irrigation and draft power as these critical inputs have been found to have the greatest effect on market participation. Further there is need for the extension service to provide high quality targeted extension support which is tailor made to meet the requirements of the different stages of the production and marketing cycles of the various enterprises.

\section{Acknowledgements}

The author is grateful to Agricultural Input Support Programme (AISP) Zimbabwe for sponsoring the field data collection exercise, the smallholder farmers in the six study districts of Manicaland and Masvingo provinces for sparing their time during survey and questionnaire administration, and to the government extension service (Agritex) and AISP team for the logistical support during the field work.

\section{References}

[1] Von Braun, J., Immink, M. D. C. (1994): Non-traditional vegetable crops and food security among smallholder farmers in Guatemala, In: von Braun J and Kennedy E (eds), Agricultural commercialization, economic development, and nutrition, Johns Hopkins University Press, Baltimore, Maryland, USA, pp. 189-203.

[2] Pingali, P. L. and M. W. Rosegrant (1995), "Agricultural Commercialization and Diversification: Processes and Policies" Food Policy, 20 (3): 171-185.

[3] Timmer C. P., (1997), Farmers and markets: The political economy of new paradigms. American Journal of Agricultural Economics, 79 (2): 621-627. 
[4] Oparinde, L. O., and Daramola, A. G. (2014). Determinants of Market Participation by Maize Farmers in Ondo State, Nigeria, Journal of Economics and Sustainable Development, 5 (1): 69-77.

[5] World Bank (2007): World Development Report 2008: Agriculture for development: Overview, Washington, DC, USA. available at: http://siteresources.worldbank.org/INTWDR2008/Resources/ WDR_00_book.pdf.

[6] IFAD (International Fund for Agricultural Development), (2003), Promoting market access for the poor in order to achieve the Millennium Development Goals. IFAD, Roundtable Discussion Paper for the 25th Anniversary Session of IFAD's Governing Council, Rome.

[7] Adeoti, A. I., Oluwatayo, I. B., and Soliu, R. O. (2014). Determinants of Market Participation among Maize Producers in Oyo State, Nigeria, British Journal of Economics, Management and Trade, 4 (7): 1115-1127.

[8] Reardon, T. and Timmer, C. P. (2007). "Transformation of Markets for Agricultural Output in Developing Countries since 1950: How has Thinking Changed?" (2808 - 2855), R. E. Evenson, and P. Pingali (Eds.). Handbook of Agricultural Economics, 3: Agricultural Development: Farmers, Farm Production and Farm Markets. Amsterdam: Elsevier Press.

[9] Gebreselassie, S., and Ludi, E. (2008): Agricultural Commercialisation in Coffee Growing Areas of Ethiopia, Future Agriculture, University of Sussex, Brighton, UK, available http://r4d.dfid.gov.uk/PDF/Outputs/Futureagriculture/coffee $p$ aper.pdf.

[10] Osimani, A. G., and Hossain, E. (2015). Market Participation Decision of Smallholder Farmers and Its Determinants in Bangladesh, Economics of Agriculture, 62 (1): 163-179.

[11] Onoja, A. O., Usoroh, B. B., Adieme, D. T., Deedam, N. J. (2012). Determinants of Market Participation in Nigerian Small-Scale Fishery Sector: Evidence from Niger Delta Region, Consilience: The Journal of Sustainable Development, 9 (1): 69-84.

[12] Abu, B. M. (2015). Groundnut Market Participation in the Upper West Region of Ghana, Ghana Journal of Development Studies, 12 (1 \& 2): 106-124.

[13] Matungul, P. M., Lyne, M. C., and Ortmann, G. F. (2001). Transaction costs and crop marketing in the communal areas of Impendle and Swayimana, KwaZulu Natal. Development Southern Africa, 18 (3): 347-363.

[14] Randela, R., Alemu, Z. G., and Groenewald, J. A. (2008). Factors enhancing market participation by small-scale cotton Farmers, Agrekon, 47 (4): 451-469.

[15] Adenegan K. O., A. Adepoju and L. O. E. Nwauwa (2012). Determinants of Market Participation of Maize Farmers in Rural Osun State of Nigeria, International Journal of Agricultural Economics and Rural Development, 5 (1): 28-39.

[16] Geoffrey, S. K., Hillary, B. K., Lawrence, K. K., and Mary, M C. (2013). Determinants of Market Participation among Small-Scale Pineapple Farmers in Kericho County, Kenya, Journal of Economics and Sustainable Development, 4 (19): 59-66.

[17] Mengstu, K. A., Kahsay, H. M., Belay, G. H., and Kassaye, A.
T. (2015). Determinants of Market Participation Decision and Level of Participation of Dairy Farmers in Tigray, Ethiopia: The case of Raya, International Journal of Current Research, 7 (3): 13512-13519.

[18] Ahmed, Y. E., Adam Bekele Girma, A. B., and Aredo, M. K. (2016). Determinants of Smallholder Farmers Participation Decision in Potato Market in Kofele District, Oromia Region, Ethiopia, International Journal of Agricultural Economics, 1 (2): 40-44.

[19] Nuri, L., Jema, H., Endrias, G., and Lemma, Z. (2016). Determinants of status and extent of Market Participation among kocho Producers in Hadiya Zone, Southern Ethiopia. International Journal of Agricultural Research Review, 4 (2): 476-485.

[20] Kassa, G., Yigezu, E., and Alemayehu, D. (2017). Determinants of smallholder market participation among banana growers in bench Maji Zone, Southwest Ethiopia, International Journal of Agricultural Policy and Research, 5 (11): 169-177.

[21] Abeykoon, M. N. D. F., Weerahewa, J., and Silva, G. L. L. P. (2013). Determinants of Market Participation by Indigenous Poultry Farmers: A Case Study in Anuradhapura District in Sri Lanka, Tropical Agricultural Research, 24 (4): 347-361.

[22] Siziba, S., Nyikahadzoi, K., Diagne, A., Fatunbi, A. O., and Adekunle, A. A. (2011). Determinants of cereal market participation by sub-Saharan Africa smallholder farmer, Learning Publics Journal of Agriculture and Environmental Studies, 2 (1): 180-193.

[23] Temesgen, G. (2014). Small Scale Irrigation and Agricultural Commercialization in Tigray, Global Journal of Commerce and management Perspective, 3 (2): 87-94.

[24] Hagos, F., Makombe, G., Namra, R. and Awulachew, S. B. (Undated). Does Access to Small Scale Irrigation Promote Market Oriented Production in Ethiopia? Available on http://publications.iwmi.org/pdf/H044080.pdf, Accessed 7 September 2018.

[25] Seyoum, C., Lemma, T., and Karippai, R. S. (2011). Factors Determining the Degree of Commercialization of Smallholder Agriculture: The Case of Potato Growers in Kombolcha District, East Hararghe, Ethiopia, Journal of Agricultural Development, 2 (1): 18-36.

[26] Tufa, A., Bekele, A., and Zemedu, L. (2013). Determinants of Smallholder Commercialization of Horticultural Crops in Gemechis District, West Hararghe Zone, Ethiopia, African Journal of Agricultural Research, 9 (3): 310-319.

[27] Gebremedhin, B., and and Jaleta, M. (2010). Commercialization of Smallholders: Does Market Orientation Translate into Market Participation? Improving Productivity and Market Success (IPMS) of Ethiopian Farmers Project Working Paper 22. Nairobi, Kenya, ILRI.

[28] Muriithi, B. W., and Matz, J. A. (2014). Smallholder Participation in the Commercialisation of Vegetables: Evidence from Kenyan Panel Data, ZEF- Discussion Papers on Development Policy No. 185, Center for Development Research, Bonn.

[29] Esmael, Y., Bekele, A., and Ketema, M. (2016). Determinants of Level of Smallholder Farmers Participation in Potato Sales in Kofele District, Oroma Region, Ethiopia, Journal of Agricultural Science and Research, 3 (2): 23-30. 
[30] Dube, L., and Guveya, E. (2013). Land Tenure Security and Farm Investments amongst Small Scale Commercial Farmers in Zimbabwe, Journal of Sustainable Development in Africa, 15 (5): 107-121.
[31] Zamasiya, B., Mango, N., Nyikahadzoi, K., and Siziba, S. (2014). Determinants of soybean market participation by smallholder farmers in Zimbabwe, Journal of Development and Agricultural Economics, 6 (2): 49-58. 